\title{
Effects of aromatic plant extract mixture on laying efficiency, egg quality and antioxidant status in laying quails
}

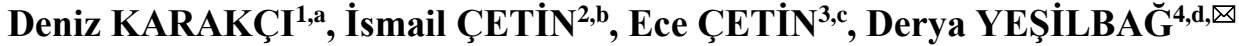 \\ ${ }^{1}$ Tekirdağ Namık Kemal University, Faculty of Veterinary Medicine, Department of Biochemistry, Tekirdağ, Turkey; ${ }^{2}$ Tekirdağ \\ Namık Kemal University, Faculty of Veterinary Medicine, Department of Animal Nutrition and Nutritional Diseases, Tekirdağ, \\ Turkey; ${ }^{3}$ Tekirdağ Namık Kemal University, Faculty of Veterinary Medicine, Department of Food Hygiene and Technology, \\ Tekirdağ, Turkey; ${ }^{4}$ Bursa Uludağ University, Faculty of Veterinary Medicine, Department of Animal Nutrition and Nutritional \\ Diseases, Bursa, Turkey \\ ${ }^{\mathrm{a} O R C I D: ~ 0000-0002-1884-1874 ;}$ ' ${ }^{\mathrm{O} O R C I D: ~ 0000-0001-7589-4852 ; ~ ' O R C I D: ~ 0000-0002-8783-5507 ; ~}$ \\ dORCID: 0000-0003-1816-2684
}

\begin{abstract}
This study aimed to evaluate the effects of commercial plant extract mixture added to laying quail rations on performance, egg quality, plasma antioxidant and blood biochemical parameters. In this experiment, 160 Japanese quails aged twelve weeks were equally divided into four groups of 40 (five replicates of 8 quails each). The study included a control and three treatment groups. The treatment groups were as follows: (1) $100 \mathrm{mg} / \mathrm{kg}$ aromatic plant extract mixture-group 1; (2) $150 \mathrm{mg} / \mathrm{kg}$ aromatic plant extract mixture-group 2 (3) $200 \mathrm{mg} / \mathrm{kg}$ aromatic plant extract mixture-group 3, respectively. When examined the egg parameters at the end of the study, significant differences $(\mathrm{P}<0.05)$ were found in the parameters of egg weight, Haugh unit $(\mathrm{HU})$, albumen index, egg yolk color and eggshell thickness. Egg weight and eggshell thickness values were measured the highest $(\mathrm{P}<0.05)$ in group 1 . HU, egg yellow color and albumen index values were found significantly higher $(\mathrm{P}<0.05)$ in all experimental groups compared to the control group. Significant differences $(\mathrm{P}<0.05)$ were determined in superoxide dismutase (SOD) and malondialdehyde (MDA) values of plasma antioxidant parameters in the study. In the study, High density lipoprotein (HDL) value, one of the blood (plasma) parameters, was found to be higher $(\mathrm{P}<0.001)$ in the experimental groups. Consequently, we can say that the addition of herbal extract mixture to quail diets increases egg quality and has a positive effect on cholesterol and plasma antioxidant parameters.
\end{abstract}

Keywords: Antioxidant, egg quality, MDA, phytobiotic, quail.

\section{Aromatik bitki ekstrakt karışımının yumurtacı bıldırcınlarda yumurta verimi, yumurta kalitesi ve antioksidan durum üzerine etkileri}

Özet: Bu çalışmada, yumurtacı bıldırcın rasyonlarına ilave edilen ticari bitkisel ekstrakt karışımının performans, yumurta kalitesi, plazma antioksidan ve biyokimyasal parametreler üzerine olan etkilerini değerlendirmek amaçlanmıştır. Deneysel çalışmada, 160 adet 12 haftalık Japon bıldırcını, her grupta 40 adet olacak şekilde eşit olarak dört gruba ayrıldı (5 alt grup her grupta 8 bıldırcın). Araştırma 1 kontrol ve 3 deneme gruplarından oluşmuştur. Deneme grupları sırasıyla: (1) $100 \mathrm{mg} / \mathrm{kg}$ aromatik bitkisel ekstrakt karışımıGrup 1; (2) 150 mg/kg aromatik bitkisel ekstrakt karışımı- Grup 2 ve (3) 200 mg/kg aromatik bitkisel ekstrakt karışımı- Grup 3 olarak oluşturuldu. Araştırma sonunda, yumurta parametreleri incelendiğinde yumurta ağırlığı, Haugh birimi, albumin indeksi, yumurta sarı rengi ve yumurta kabuk kalınlığı parametrelerinde önemli farklılıklar $(\mathrm{P}<0,05)$ tespit edildi. Yumurta ağırlığı ve yumurta kabuk kalınlığ 1 değerleri en yüksek $(\mathrm{P}<0,05)$ grup 1'de ölçüldü. Haugh birimi, yumurta sarı rengi ve albumin indeksi değerleri kontrol grubuyla kıyaslandığında tüm deneme gruplarında anlamlı derecede $(\mathrm{P}<0,05)$ yüksek bulundu. Araştırmada kan plazma antioksidan parametrelerinden SOD ve MDA değerlerinde önemli düzeyde $(\mathrm{P}<0,05)$ farklılıklar belirlendi. Araştırmada, kan parametrelerinden HDL değeri deneme gruplarında daha yüksek olarak $(\mathrm{P}<0,001)$ tespit edildi. Sonuç olarak bıldırcın diyetlerine bitki ekstrakt karışımı ilavesinin yumurta kalitesini artırdığını, kolesterol ve plazma antioksidan parametreleri üzerinde olumlu etkisi olduğunu söyleyebiliriz. Anahtar sözcükler: Antioksidan, bıldırcın, fitobiyotik, MDA, yumurta kalitesi. 


\section{Introduction}

Today, poultry breeding contributes to meeting the needs of people with meat and egg products and animal protein with its suitability for industrial production and low price. Most of the poultry production is more economical than the production of livestock species. Antibiotics, which are used as growth promoters in poultry diets, have ensured that the increasing demands for poultry products are met rapidly and resulted in efficiency. However, the use of antibiotics in rations as feed additives was prohibited in 2006 due to the fact that they leave residues in animal products and cause the development of resistant bacteria. After the prohibition of antibiotics used as growth and health promoters in livestock, feed additives that can be used as an alternative to antibiotics have been investigated in order to minimize the incurred losses of the poultry and livestock sector (6). As in this research, aromatic plants and plant extracts defined as phytobiotics are added to animal feeds as feed additives. Phytobiotics with biological and aromatic properties can be added directly or used in the form of extract acquired from these plants. In addition to their aromatic effects, phytobiotics have antioxidative, antifungal, anticarcinogenic, antiinflammatory, and antimicrobial effects. Besides, these plants have been utilized for centuries to extend the shelf life of foods (43).

Phytobiotics, which are added to poultry feeds as additives, are supplemented to increase the digestibility and consumption of feeds, to improve performance or the quality of the products obtained (42). In the study, a new generation plant extract mixture with the active ingredients of Sanguinarine, Honokiol and Magnolol was used in order to benefit from its biological activities. Sanguinarine is a plant extract obtained from the plants Macleya cordata and Sanguinaria Canadensis (1, 17). Sanguinarine is a quaternary benzo [c] phenanthyridine (QBA) alkaloid belonging to the Papaveraceae family $(14,26)$. The pure alkaloid form of this active ingredient was used as a traditional medical drug in North America, Europe, and China it was isolated several years ago. It was found that sanguinarine which has antibacterial (18), antiinflammatory (27), antiviral (10), antifungal (33), antitumoral (12), and immunomodulator (15) effects, reduces amino acid degradation in small intestines with its addition to poultry feed (16). However, Banerjee et al. (4) reported that serum sanguinarine levels were positively correlated with serum MDA levels in their study. In the study conducted by Vieira et al. (38), it was found that the addition of sanguinarine to broiler rations increased their live weight in the $3^{\text {rd }}$ week. Magnolia officinalis is a plant belonging to the Magnoliaceae family, also called 'houpu' (shell part is 'hou', the remaining part is 'pu') which has been used traditionally in China for a long time $(31,37)$. This herb is used in China for the treatment of acute pain, diarrhea, cough, and urinary system problems (13). The main active compounds of $M$. officinalis are Magnolol and Honokiol. These compounds act for lipid peroxidation and inhibition of free radicals (25). It also provides bacteriostatic, anti-inflammatory, antitumoral, and antimicrobial activities $(9,40)$. In addition, it is also used in the medical, pharmaceutical, and cosmetic industry (20).

This study aimed to investigate the effects of the combined use of the plant extracts in question. For this purpose, the effects of sanguinarine, honokiol and magnolol extract mixture added to laying quail rations on egg quality, plasma antioxidant and biochemical values and performance parameters were examined.

\section{Materials and Methods}

Animals and Diets: A total of 160 Japanese quails (Coturnix coturnix japonica) aged twelve weeks were housed in cages and were randomly allocated to four treatment groups each consisting of 40 quails. Each group was divided into 5 subgroups. The quails were kept in laying cages (100 cm wide, $45 \mathrm{~cm}$ deep, $21 \mathrm{~cm}$ high in front, and $17 \mathrm{~cm}$ high in the rear, $112.5 \mathrm{~cm} 2$ per quail) and housed there until the end of the study. Feed and water were provided ad libitum. The quails received a basal diet (maize and soya bean based; $16.8 \%$ crude protein; 2720 $\mathrm{kcal} / \mathrm{kg}$ Metabolisable energy-ME) that was formulated to meet the NRC (National Research Council) (28) requirements for nutrients, including vitamins and minerals. The diet did not contain antibiotics, coccidiostats or growth promoters. The content of the basal diet is presented in Table 1. Group feeding was used in all treatment groups. The one control group and 3 treatment groups were treated as follows: $0 \mathrm{mg}$ additive of diet (control); (1) with the addition of $100 \mathrm{mg} / \mathrm{kg}$ aromatic plant extract mixture (2) with the addition of $150 \mathrm{mg} / \mathrm{kg}$ aromatic plant extract mixture (3) with the addition of 200 $\mathrm{mg} / \mathrm{kg}$ aromatic plant extract mixture. The levels of product were decided as per the manufacturer recommendations. The aromatic plant extract Filopower, a natural growth promoter, was supplied by Yem-Vit A.Ş (İzmir, Turkey). The aromatic plant extract mixture included 50\% wheat middlings, $24 \%$ mixing of flavoring compounds (Magnolia, Sanguinarina), 23.5\% calcium carbonate, $2 \%$ of products and by-products of tubers and roots and $0.5 \%$ barley meal (unit given by the manufacturer). During the experimental period, the 24hour constant lighting program was maintained at 16 hours light and 8 hours dark. The experiment was conducted for 10 weeks. The study protocol was approved by Ethics Committee of Tekirdağ Namık Kemal University Approval number: T 2018-3/1). The nutritional composition of the diets was determined according to the AOAC (Association of Official Analytical Chemists) (3). 
ME levels of diets were estimated using the equation created by Carpenter and Clegg (21): $\mathrm{ME}, \mathrm{kcal} / \mathrm{kg}=53+$ $38[(\mathrm{CP}, \%)+(2.25 \times$ ether extract, \% $)+(1.1 \times$ starch, \% $)$ $+($ sugar, $\%)]$.

Performance Parameters: The quails were weighed twice, at the beginning and at the end of the experiment, and their live weight was determined. The feeds were weighed every two weeks and the feed consumption was recorded as the group average. The feed conversion rate (FCR) was calculated as the amount of feed consumed for a dozen egg production. In order to calculate the egg production, the number of eggs was noted every day at the same time. Eggs collected every 15 days were kept for 24 hours, and then the egg weight was determined by weighing them on a precision scale (Sartorius, Model BSA224S-CW, Germany). After the weight of the eggs and egg yield percentage obtained from the groups were determined, the egg mass was calculated using these values.

Egg mass = Egg weight $\mathrm{x}$ Egg yield/100

Antioxidant and Biochemical Parameters: During the $70^{\text {th }}$ day of the study, the animals were slaughtered for blood collection. During the slaughter, blood samples of 40 animals in total, 10 randomly from each group, were taken into tubes containing $2 \mathrm{ml}$ anticoagulant $\left(\mathrm{K}_{3}\right.$ EDTA). The blood samples were centrifuged at $3000 \mathrm{rpm}$ for 10 minutes, transferred to plasma microtubes and stored at $-20^{\circ} \mathrm{C}$ until the day of analysis. The changes of antioxidant parameters in plasma including SOD (Superoxide Dismutase) (Catalog no: K-335-100 Biovision, USA) GSH-Px (Glutathione Peroxidase), (Catalog no: K762-100 Biovision, USA) TAC (Total Antioxidant Capacity) (Rel Assay Diagnostic, Turkey) TOC (Total Oxidant Capacity) (Rel Diagnostic Assay, Turkey), MDA (Malondialdehyde) (Catalog number: 20116-0161 Sunred Biological Technology Co., Ltd., China), CAT (Catalase) (Catalog number: 201-16-0159 Sunred Biological Technology Co., Ltd, China) were measured by using commercial kits using ELISA method and biochemical parameters such as Total Protein, Albumin, Total Cholesterol, HDL, LDL (Low Density Lipoprotein), Triglyceride were evaluated using spectrophotometric and colorimetric methods by a microplate reader (Thermo Scientific Multiskan Go, USA).

Egg Quality Parameters: On the $15^{\text {th }}, 30^{\text {th }}, 45^{\text {th }}, 60^{\text {th }}$, and $70^{\text {th }}$ days of the study, 8 eggs (total 40 egg per groups) of the last two days from each subgroup were collected and egg weight, shape index, shell thickness, shell weight, egg shell breaking strength were determined in order to examine the external quality characteristics while the albumen index, yolk index, yolk color, and HU were defined to examine the internal quality characteristics (2). In determining the egg weight and shell thickness, the eggs were weighed $(\mathrm{g})$ and recorded after taring on a scale with
0.0001 precision (Sartorius, Model BSA224S-CW, Germany). The shape index value is measured by placing the width and length of each egg, the widest and longest points of the egg on a digital caliper (Caliper, Mitutoyo Code No.500-181-20, Model CD-15CPx, Japan), and then the shape index value was calculated by adding these two values to the formula $=$ egg width $(\mathrm{mm}) /$ egg length $(\mathrm{mm})$ x100. In determining the shell thickness of the eggs, the outer and inner membranes of three separate pieces, one from each of the two ends and middle parts of the egg, were peeled, and each was measured by placing it in a digital caliper. Average shell thickness was found by taking the arithmetic mean of these three values. In order to determine the egg shell breaking strength of the eggs, each egg was placed vertically and with the blunt end upwards on the egg shell breaking strength measuring device (Push Pull Scale, Imada, Model No. SU-05, Japan). Then the upper vice of the device was slid downwards and tightened so that there was no gap between the vice and the egg. The vice was then gently pushed further down to the breaking point of the egg and the value read on the scale at the breaking point was recorded as Newton $/ \mathrm{cm} 2$ $(\mathrm{N} / \mathrm{cm} 2)$. In determining the albumen index, firstly, after each egg was broken without dispersing on a glass plate, the albumen height and albumen length were measured with a digital caliper and the albumen height was recorded with a tripod micrometer. The formula of albumen index $=$ (albumen height $(\mathrm{mm})$ /average of length and width (mm)) x100 was used to calculate the index. HU in egg was determined using the values of egg weight-g $(\mathrm{G})$ and albumin height-mm $(\mathrm{H}) . \mathrm{HU}=100 \log (\mathrm{H}+7.57$ 1.70G0.37). In order to assign the yolk index, first, yolk height and yolk width were measured with a digital caliper after breaking each egg without spreading on a plate. The calculation was made using the formula yolk index $=$ yolk height (mm) / yolk width (mm) x 100. Roche color scale consisting of 15 slices was used to measure the color of egg yolk (DMS, 2005-HMB, 51548, Switzerland).

Statistical Analysis: In the statistical analysis of live weight, feed consumption, FCR, biochemical parameters, egg yield and quality, a One Way ANOVA was applied for the variables meeting the parametric test assumptions while when statistical differences were found between the groups, a Duncan multiple comparison test was used to identify in which group or groups the difference was (35). Statistical significance was determined at $\mathrm{P}<0.05$. Linear and quadratic effects of dietary plant extract mixture inclusion level were studied using polynomial contrasts. Statistical analyses were performed with the SPSS 21 package program (SPSS Inc., Chicago, IL, USA). Statistical analysis was carried out using the SPSS 10.00 (36) software package for Windows (SPSS Inc., Chicago, IL, USA). 


\section{Results}

The ingredient and chemical composition of the diets is shown in Table 1. The effects of aromatic plant extract mixtures on some quail performance parameters are presented in Table 2. In the study, no difference $(\mathrm{P}>0.05)$ was found in terms of starting and ending live weights of quails. But plant extract mixture addition increased finally live weight quadratically $(\mathrm{P}<0.05)$. When the results were examined, it was seen that the egg weight data in the first group were higher than the control and group $2(\mathrm{P}<0.001)$ and quadratic $(\mathrm{P}<0.01)$. There was no statistically significant difference between the control and experimental groups in terms of egg mass, feed intake and FCR $(P>0.05)$. The effects of dietary treatments on some egg quality characteristics are given in Table 3 . The data clearly show that although the difference in shape index, yolk index, egg shell breaking strength and eggshell weights were not significant between groups $(\mathrm{P}>0.05)$, $\mathrm{HU}$, albumen index, yolk colour and egg shell thickness were significantly different $(\mathrm{P}<0.05)$. Among these parameters, the albumen index was not found quadratically significant. The highest values in these parameters (HU, albumen index, yolk color and eggshell thickness) were measured in experimental groups. The $\mathrm{HU}$ and albumen index values, measures of egg quality, were found to be high in the experimental groups. These values show us that additives can contribute to improving egg quality. Yolk colour was significantly improved in the all treatment groups compared with the control group. The effect of dietary treatments on plasma antioxidant parameters are shown in Table 4. In the study, while plasma SOD and MDA values differed $(\mathrm{P}<0.05)$ between control and experimental groups, no difference was observed
Table 1. Ingredients and chemical composition of basal diet.

\begin{tabular}{lr}
\hline Ingredients & $\mathrm{g} / \mathrm{kg}$ \\
\hline Maize, Grain & 590 \\
Soybean meal & 208 \\
Full fat soybean & 110 \\
Sunflower meal & 46 \\
Wheat & 27 \\
Monocalcium phosphate & 8.5 \\
Salt & 2.5 \\
Vit-Min premix ${ }^{\mathrm{a}}$ & 3.5 \\
DL-methionine & 1.6 \\
Sodium bicarbonate & 1 \\
Choline choloride & 0.8 \\
Phytase & 0.6 \\
Toxin binder & 0.5 \\
\hline Analyse concentrations, $\mathrm{g} / \mathrm{kg}$ & \\
\hline Metabolisable energy ${ }^{\mathrm{k}} \mathrm{kcal} / \mathrm{kg}$ & 2720 \\
Crude protein & 168.2 \\
Crude fat & 42.8 \\
Ash & 118 \\
Dry matter & 885.2 \\
Calcium & 3.73 \\
Phosphorus & 0.64 \\
\hline
\end{tabular}

aProvides (per $\mathrm{kg}$ diet): Vit A (retinol), $2.4 \mathrm{mg}$; Vit $\mathrm{D}_{3}$ (cholecalciferol), $0.075 \mathrm{mg}$; Vit E ( $\alpha$-tocopherol acetate) 20 $\mathrm{mg}$;Vit $\mathrm{B}_{1}$ (thiamine), 3mg; Vit $\mathrm{B}_{2}$ (riboflavin), $3 \mathrm{mg}$; Vit $\mathrm{B}_{6}$ (pyridoxal), $3.5 \mathrm{mg}$; Vit $\mathrm{B}_{12}$ (cobalamin), $0.01 \mathrm{mg}$; Niacine, 20 $\mathrm{mg}$; Calcium d-pantothenate, $4 \mathrm{mg}$; Folic acid, $1 \mathrm{mg}$; Choline, $600 \mathrm{mg}$; Biotin, $0.03 \mathrm{mg}$; Mn, $80 \mathrm{mg}$; Fe, 60 mg; Zn, $60 \mathrm{mg}$; Cu, $5 \mathrm{mg}$; I, $1 \mathrm{mg}$; Co, $0.2 \mathrm{mg}$; Se, $0.15 \mathrm{mg}$

${ }^{b}$ Metabolisable energy content of diets was estimated using the equation devised by Carpenter and Clegg.

Table 2. Effects of aromatic plant extract mixture on performance parameters.

\begin{tabular}{|c|c|c|c|c|c|c|}
\hline \multirow[b]{3}{*}{ Parameters } & \multirow[b]{3}{*}{ Control } & \multirow[b]{3}{*}{ Group 1} & \multirow[b]{3}{*}{ Group 2} & \multirow[b]{3}{*}{ Group 3} & \multicolumn{2}{|c|}{ Statistical analyses $^{1}$} \\
\hline & & & & & \multicolumn{2}{|c|}{ Polynominal contrasts } \\
\hline & & & & & P-linear & P-quadratic \\
\hline $\begin{array}{l}\text { Live weight } \\
\text { (initially),g }\end{array}$ & $234.27 \pm 4.56$ & $239.89 \pm 4.56$ & $236.59 \pm 4.61$ & $232.71 \pm 5.97$ & 0.720 & 0.340 \\
\hline Live weight (finally),g & $249.33 \pm 5.99$ & $266.78 \pm 6.32$ & $256.42 \pm 5.72$ & $268.92 \pm 8.28$ & 0.101 & 0.033 \\
\hline Feed intake, g/day & $41.80 \pm 0.77$ & $42.98 \pm 1.08$ & $39.86 \pm 0.96$ & $40.89 \pm 1.14$ & 0.209 & 0.940 \\
\hline Egg yield, \% & $91.28 \pm 1.22$ & $86.61 \pm 2.00$ & $89.00 \pm 1.49$ & $90.07 \pm 1.03$ & 0.311 & 0.109 \\
\hline Egg weight, g & $11.96 \pm 0.10^{\mathrm{c}}$ & $12.62 \pm 0.07^{\mathrm{a}}$ & $12.26 \pm 0.07^{\mathrm{b}}$ & $12.42 \pm 0.12^{\mathrm{ab}}$ & 0.024 & 0.011 \\
\hline Feed conversion rate ${ }^{2}$ & $0.55 \pm 0.007$ & $0.59 \pm 0.02$ & $0.54 \pm 0.01$ & $0.54 \pm 0.015$ & 0.191 & 0.188 \\
\hline Egg mass, g/quail/day & $10.93 \pm 0.24$ & $10.97 \pm 0.32$ & $10.91 \pm 0.25$ & $11.11 \pm 0.18$ & 0.679 & 0.753 \\
\hline
\end{tabular}


in other plasma parameters. The plasma SOD level was measured in the group 2 with the most different $(\mathrm{P}<0.05)$ and the highest value, while the lowest plasma MDA value was measured in the group $1(\mathrm{P}<0.05)$. However, the plasma SOD value did not constitute a quadratic significance. In the study, biochemical plasma albumin, total protein, LDL, HDL, triglyceride and total cholesterol parameters are presented in Table 5. When the HDL value was examined in the study, it was found that there was a statistically significant difference between the groups and the HDL values were at the highest level in the group 2 and group 3 groups $(\mathrm{P}<0.05)$.

Table 3. Effects of aromatic plant extract mixture on egg quality parameters.

\begin{tabular}{|c|c|c|c|c|c|c|}
\hline \multirow[b]{3}{*}{ Parameters } & \multirow[b]{3}{*}{ Control } & \multirow[b]{3}{*}{ Group 1} & \multirow[b]{3}{*}{ Group 2} & \multirow[b]{3}{*}{ Group 3} & \multicolumn{2}{|c|}{ Statistical analyses $^{1}$} \\
\hline & & & & & \multicolumn{2}{|c|}{ Polynominal contrasts } \\
\hline & & & & & P-linear & $P$-quadratic \\
\hline Shape index & $81.84 \pm 0.26$ & $81.16 \pm 0.28$ & $81.75 \pm 0.29$ & $81.81 \pm 0.28$ & 0.161 & 0.197 \\
\hline Haugh unit & $90.03 \pm 0.41^{\mathrm{b}}$ & $92.00 \pm 0.36^{\mathrm{a}}$ & $91.38 \pm 0.31^{\mathrm{a}}$ & $91.58 \pm 0.36^{\mathrm{a}}$ & 0.007 & 0.04 \\
\hline Albumen index & $12.14 \pm 0.20^{\mathrm{b}}$ & $12.87 \pm 0.15^{\mathrm{a}}$ & $12.80 \pm 0.15^{\mathrm{a}}$ & $12.68 \pm 0.16^{\mathrm{a}}$ & 0.035 & 0.344 \\
\hline Yolk index & $49.88 \pm 0.39$ & $49.63 \pm 0.19$ & $49.26 \pm 0.20$ & $49.27 \pm 0.28$ & 0.826 & 0.701 \\
\hline Yolk colour & $3.18 \pm 0.06^{\mathrm{c}}$ & $3.51 \pm 0.06^{\mathrm{ab}}$ & $3.69 \pm 0.07^{\mathrm{a}}$ & $3.42 \pm 0.07^{\mathrm{b}}$ & 0.004 & 0.001 \\
\hline Eggshell thickness, $\mu \mathrm{m}$ & $14.83 \pm 0.11^{\mathrm{d}}$ & $16.83 \pm 0.11^{\mathrm{a}}$ & $16.05 \pm 0.12^{b}$ & $15.65 \pm 0.12^{\mathrm{c}}$ & 0.002 & 0.001 \\
\hline Eggshell breaking strength, $\mathrm{N}$ & $12.72 \pm 0.18$ & $13.36 \pm 0.24$ & $13.23 \pm 0.19$ & $13.10 \pm 0.16$ & 0.253 & 0.063 \\
\hline Eggshell weight, g & $1.84 \pm 0.02$ & $1.88 \pm 0.02$ & $1.84 \pm 0.02$ & $1.86 \pm 0.02$ & 0.817 & 0.857 \\
\hline
\end{tabular}

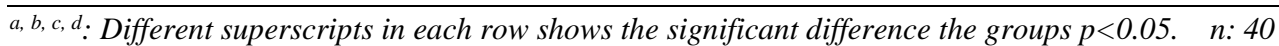

1. The statistical analysis tests the differences between treatment groups (ANOVA) and thelinear-quadratic effect of plant extract mixture inclusion levels (polynominal contrasts)

Table 4. Effects of aromatic plant extract mixture on plasma antioxidant parameters.

\begin{tabular}{|c|c|c|c|c|c|c|}
\hline \multirow[b]{3}{*}{ Parameters } & \multirow[b]{3}{*}{ Control } & \multirow[b]{3}{*}{ Group 1} & \multirow[b]{3}{*}{ Group 2} & \multirow[b]{3}{*}{ Group 3} & \multicolumn{2}{|c|}{ Statistical analyses $^{1}$} \\
\hline & & & & & \multicolumn{2}{|c|}{ Polynominal contrasts } \\
\hline & & & & & P-linear & P-quadratic \\
\hline GSH-Px $(\mathrm{mmol} / \mathrm{min} / \mathrm{ml})$ & $93.83 \pm 6.33$ & $114.70 \pm 7.92$ & $105.87 \pm 7.01$ & $112.26 \pm 6.27$ & 0.142 & 0.303 \\
\hline $\mathrm{SOD}(\mathrm{U} / \mathrm{ml})$ & $96.14 \pm 6.05^{b}$ & $93.64 \pm 5.71^{\mathrm{b}}$ & $123.41 \pm 8.24^{\mathrm{a}}$ & $101.26 \pm 5.13^{\mathrm{b}}$ & 0.123 & 0.133 \\
\hline CAT (ng/ml) & $44.90 \pm 1.75$ & $48.61 \pm 1.60$ & $51.01 \pm 1.77$ & $50.62 \pm 1.83$ & 0.500 & 0.248 \\
\hline MDA (nmol/ml) & $20.81 \pm 0.71^{\mathrm{a}}$ & $18.16 \pm 0.72^{b}$ & $19.15 \pm 0.57^{\mathrm{ab}}$ & $19.88 \pm 0.56^{\mathrm{ab}}$ & 0.021 & 0.013 \\
\hline TAS (mmol/L) & $0.68 \pm 0.06$ & $0.65 \pm 0.05$ & $0.85 \pm 0.07$ & $0.86 \pm 0.09$ & 0.420 & 0.770 \\
\hline $\operatorname{TOS}(\mu \mathrm{mol} / \mathrm{L})$ & $4.05 \pm 0.36$ & $3.64 \pm 0.46$ & $5.11 \pm 0.46$ & $4.70 \pm 0.51$ & 0.102 & 1.00 \\
\hline
\end{tabular}

${ }^{a, b}$ : Different superscripts in each row shows the significant difference between the groups $p<0.05 . n: 10$

${ }^{1}$ :The statistical analysis tests the differences between treatment groups (ANOVA) and the linear-quadratic effect of plant extract mixture inclusion levels (polynominal contrasts)

Table 5. Effects of aromatic plant extract mixture on biochemical parameters.

\begin{tabular}{|c|c|c|c|c|c|c|}
\hline \multirow[b]{3}{*}{ Parameters } & \multirow[b]{3}{*}{ Control } & \multirow[b]{3}{*}{ Group 1} & \multirow[b]{3}{*}{ Group 2} & \multirow[b]{3}{*}{ Group 3} & \multicolumn{2}{|c|}{ Statistical analyses $^{I}$} \\
\hline & & & & & \multicolumn{2}{|c|}{ Polynominal contrasts } \\
\hline & & & & & $P$-linear & $P$-quadratic \\
\hline Albumin (g/dl) & $2.20 \pm 0.08$ & $2.26 \pm 0.09$ & $2.37 \pm 0.04$ & $2.23 \pm 0.06$ & 0.568 & 0.207 \\
\hline HDL (mg/dl) & $53.32 \pm 3.21^{\mathrm{c}}$ & $62.83 \pm 2.89^{\mathrm{b}}$ & $74.13 \pm 3.61^{\mathrm{a}}$ & $72.40 \pm 3.23^{\mathrm{a}}$ & 0.001 & 0.092 \\
\hline LDL (mg/dl) & $61.87 \pm 4.43$ & $44.76 \pm 6.75$ & $48.49 \pm 5.86$ & $40.81 \pm 4.25$ & 0.295 & 0.390 \\
\hline Triglyceride (mg/dl) & $276.10 \pm 17.05$ & $259.78 \pm 24.93$ & $245.04 \pm 13.59$ & $243.79 \pm 10.10$ & 0.082 & 0.862 \\
\hline Total Cholesterol (mg/dl) & $139.41 \pm 5.02$ & $129.96 \pm 12.07$ & $142.64 \pm 7.09$ & $129.36 \pm 4.38$ & 0.618 & 0.807 \\
\hline Total Protein (g/dl) & $5.78 \pm 0.29$ & $5.24 \pm 0.24$ & $5.26 \pm 0.39$ & $5.58 \pm 0.44$ & 0.793 & 0.830 \\
\hline
\end{tabular}

$\overline{a, b, c}:$ Different superscripts in each row shows the significant difference between the groups $P<0.05 . n: 10$

${ }^{1}$ :The statistical analysis tests the differences between treatment groups (ANOVA) and the linear-quadratic effect of plant extract mixture inclusion levels (polynominal contrasts). 


\section{Discussion and Conclusion}

In this study, no statistically significant difference was found between the groups in terms of performance parameters, feed intake, egg yield, egg mass and FCR. Only significant difference was detected in egg weight. The lowest egg weight was measured in the control group. Studies on the use of aromatic plant or plant mixtures have found various effects on performance parameters. In parallel with the results of the study, Kozlowski et al. (19) reported that the addition of Macleaya cordata to broiler diets had no significant effect on feed intake, live weight gain and FCR. In another study, it was concluded that the addition of sanguinarine to the ration generally had no effect on body weight and FCR during the initial or development periods (15). Unlike this study, Vieira et al. (38) revealed that sanguinarine added to broiler diets increased the live weight of animals in the 3 rd week. In addition, Yesilbag et al. (45) found that the addition of aromatic plant extract mixture (sanguinarine, magnolol, honokiol) to broiler ration at the level of $100 \mathrm{ppm}$ caused a significant increase in total feed consumption. It shows that the increase in feed consumption is due to the positive effect of the aromatic plant used on the palatability of the feed. In the study, egg weight in group 1 was statistically higher than the control and other groups. We can say that the increase in the weight of the eggs collected from this group in the study may be due to this group's consumption of more feed. In another study, it was observed that egg weight increased with the addition of $200 \mathrm{mg} / \mathrm{kg}$ of resveratrol, which also has antioxidant properties, to the laying hen rations (46).

The effects of dietary treatments on internal and external quality parameters of eggs are shown in Table 3. In the study, it was found that the addition of aromatic plant extract mixture to quail diets significantly increased in terms of HU, albumen index, egg yolk color and eggshell thickness parameters compared to the control group, resulting in improvements in egg quality in these groups. According to the results of the literature review, no data could be found on the use of the herbal extract mixture we used in the study in poultry laying animals. However, there are studies on the use of other aromatic plant and extracts in layers, and it has been found that the addition of aromatic plant extract mixtures generally can a positive improvement in egg quality, especially yolk color (44). It was found that the essential oil mixture of rosemary and thyme added in high doses to quail rations increased the egg yolk color, yolk and albumen index (44). In another study in which ginger was added to the ration as a feed additive, when the egg quality parameters were examined, it was seen that there was no statistically significant difference (41). In the research, the highest HU value among the egg quality parameters was determined in the experimental groups. The HU is known as an indicator of egg freshness and is related to shelf life. The HU results in this study were similarly affected positively. The improvement in this characteristic shows that the phytobiotic mix can improve the egg quality parameter on shelf life. Similarly, it has been reported that the addition of $300 \mathrm{mg} / \mathrm{kg}$ antioxidant juniper oil to the laying hen ration increases the $\mathrm{HU}$ value (8). Botsoglou et al. (7) reported a significant effect on egg weight, egg shape index, yolk index, HU and eggshell thickness from rosemary, oregano, saffron and $\alpha$-tocopheryl acetate supplementation of hen diets. Another study found that dietary thyme oil supplementation did not make a significant difference in egg weight, egg shape index, yolk diameter, yolk height, yolk color, HU, and egg shell thickness (11).

Some active compounds extracted from plants can be used as an alternative to oxidative stress control due to their capacity to neutralize free radicals. These compounds include honokiol and its isomer magnolol and sanguinarine, which are extracted from the plants of Magnolia officinalis and Macleaya cordata, respectively (22). When SOD values were examined in the study, it was seen that the SOD value of group 2 has a higher value compared to the control and other groups. In a study conducted on ducks, it was found that magnolol increased the mRNA levels in hepatic SOD, CAT and GSH-Px (23).

Magnolol and honokiol were found to have a protective effect through an antioxidant effect against liver damage caused by D-galactosamine which is a hepatotoxic agent. Thus, magnolol and honokiol inhibit intracellular GSH-Px depletion (30). In parallel with this situation, in the study of Pang et al. (29) conducted in mice, it was determined that CAT, GSH-Px and SOD activities were higher in the group given $100 \mathrm{mg} / \mathrm{ml}$ through gavage than the control and other groups.

Reactive oxygen species (ROS), hydroxyl $\left(\mathrm{OH}^{-}\right)$ radical and superoxide radical $\left(\mathrm{O}^{-2}\right)$ are formed from the partial reduction of the oxygen molecule. Endogenous sources in ROS production (free radicals produced by the body's own functioning), especially the radicals leaking from electron transport systems in unhealthy mitochondria are the most important free radical source. In lipid peroxidation, it causes a decrease in the ratio of unsaturated fatty acids. As a result of this reaction, fatty acid hydroperoxides and aldehyde compounds are formed and tissue destruction occurs. The thiobarbituric acid (TBA) reaction used to measure this lipid peroxidation is the most used method due to its ease and sensitivity. TBA is used to detect lipid peroxidation products that are converted to MDA (34). In the study, the plasma MDA values which determine the amount of lipid peroxidation were found to be at the lowest levels in the group 1. This 
may indicate that the aromatic plant extract mixture given at this dose prevents lipid peroxidation and provides an antioxidant effect metabolically. In addition, in the study conducted by Bavarsadi et al. (5) it was found that the MDA ratios were the lowest in the group which $7.5 \mathrm{mg} / \mathrm{kg}$ of sanguinarine was added to laying hens feed. Many studies have proved that the addition of polyphenol compounds, into poultry and livestock feeds protect many tissues and organs against diseases and show antioxidant activity $(24,39)$. It has been demonstrated by Shen et al. (32) that Magnolol, a polyphenol compound, has antioxidant activity. In this study, no statistically significant differences were found among the groups in terms of CAT, TOS (Total Oxidant Status), TAS (Total Antioxidant Status) plasma antioxidant parameters. As it is known, HDL prevents the presence of high amounts of cholesterol in the blood by carrying cholesterol from tissues and vessels to the liver. High levels of cholesterol in the blood damage blood vessels. As HDL removes excess cholesterol from the blood, it is commonly called 'good cholesterol'. When the plasma HDL lipoprotein value, one of the biochemical parameters, was examined, the HDL values of group 2 and group 3 were measured at the highest level. Contrary to this finding, no change in serum HDL and triglyceride levels was found in a study where different doses of sanguinarine were added to the feed (5). In order to support the study findings, studies are needed to examine the relationship between the aromatic plant mixture containing the same active ingredients and the blood HDL level.

It was determined that the use of extracts of Macleaya Cordata and Magnolia tree together on laying quail rations caused statistically significant differences between groups in egg quality parameters, plasma antioxidant and biochemical parameters. According to the results of the literature reviews, there are not many studies investigating the effect of the new generation aromatic plant extract mixture, also called phytobiotic. For this reason, evaluating the subject of the study together with the performance and blood parameters can add value to future studies in terms of discussion. However, more research is needed on this subject in order to make more meaningful interpretations. As a result, it is thought that the new generation plant extract mixture has natural, residue-free, egg quality enhancing and antioxidant properties that are introduced to the market as an alternative to antibiotics. Due to these properties, it is concluded that the use of phytobiotic extract mixture in rations of laying quail may provide beneficial effects.

\section{Acknowledgments}

We would like to thank Yem-Vit ${ }^{\circledR}$ company for providing the feed additive we used in our study.

\section{Financial Support}

This study was supported by Tekirdağ Namık Kemal University Scientific Research Unit Grant (Project No: NKUBAP.10.GA.19.212).

\section{Ethical Statement}

This study was approved by the Tekirdağ Namık Kemal University Animal Experimentation Local Ethics Committee (T 2018-3/1).

\section{Conflicts of Interest}

The authors declare no conflicts of interest.

\section{References}

1. Agarwal S, Reynolds MA, Pou S, et al (1991): The effect of sanguinarine on human peripheral blood neutrophil viability and functions. J Oral Microbiol, 6, 51-61.

2. Anar S (2016): Yumurta ve Yumurta Ürünleri. Dora Basin Yayın Dağıtım Ltd. Sti. $1^{\text {st }}$ Press, Bursa, Turkey.

3. AOAC (2000): Official methods of analysis. $17^{\text {th }}$ ed. Association of Official Analytical Chemists, 2000, Maryland. USA.

4. Banerjee BD, Seth V, Koner BC, et al (2000): Evaluation of oxidative stress in some cases of argemone oil poisoning during a recent outbreak of epidemic dropsy in India. Int $\mathrm{J}$ Environ Health Res, 10, 341-346.

5. Bavarsadi M, Mahdavi AH, Ansari-Mahyari S, et al (2017): Effects of different levels of sanguinarine on antioxidant indices, immunological responses, ileal microbialcounts and jejunal morphology of laying hens fed diets with different levels of crude protein. $\mathrm{J}$ Anim Physiol Anim Nutr, 101, 936-948.

6. Bilal T, Keser O, Abas I (2008): Esansiyel yağların hayvan beslemede kullanılmasl. Erciyes Üniv Vet Fak Derg, 5, 41-50.

7. Botsoglou N, Florou-Paneri P, Botsoglou E, et al (2005): The effect of feeding rosemary, oregano, saffron and $\alpha$ tocopheryl acetate on hen performance and oxidative stability of eggs. S Afr J Anim Sci, 35, 143-151.

8. Cengiz SS, Yesilbag D, Meral Y, et al (2015): Juniper oil improves oxidative stability and eggshell and albumin quality of quail eggs. Br Poult Sci, 56, 58-65.

9. Clark AM, Elferaly FS, Li WS (1981): Antimicrobial activity of phenolic constituents of Magnolia grandiflora. J Pharmacol Sci, 70, 951-952.

10. Colombo ML, Bosisio E (1996): Pharmacological activities of Chelidonium majus L. (Papaveraceae). Pharmacol Res, 33, 127-134.

11. Florou-Paneri P, Nikolakakis I, Giannenas I, et al (2005): Hen performance and egg quality as affected by dietary oregano essential oil and $\alpha$-tocopheryl acetate supplementation. Int J Poult Sci 4, 449-454.

12. Hammerová J, Uldrijan S, Táborská E, et al (2011): Benzo[c] phenanthridine alkaloids exhibit strong antiproliferative activity in malignant melanoma cells regardless of their p53 status. J Dermatol Sci, 62, 22-35.

13. Ho KY, Tsai CC, Chen CP, et al (2001): Antimicrobial activity of honokiol and magnolol isolated from Magnolia officinalis. Phytother Res, 15, 139-141. 
14. Hu NX, Chen M, Liu YS, et al (2019): Pharmacokinetics of sanguinarine, chelerythrine, and their metabolites in broiler chickens following oral and intravenous administration. J Vet Pharmacol Ther, 42, 197-206.

15. Juskiewicz J, Gruzauskas R, Zdunczyk Z, et al (2011): Effects of dietary addition of Macleaya cordata alkaloid extract on growth performance, caecal indices and breast meat fatty acids profile in male broilers. J Anim Physiol Anim Nutr, 95, 171-178.

16. Kantas D, Papatsiros GV, Tassis PD (2015): The effect of a natural feed additive (Macleaya cordata), containing sanguinarine, on the performance and health status of weaning pigs. Anim Sci J, 86, 92-98.

17. Kosina P, Walterova D, Ulrichova J, et al (2003): Sanguinarine and chelerythrine: assessment of safety on pigs in ninety days feeding experiments. Food Chem Toxicol, 42, 85-91.

18. Kosina P, Walterova D, Ulrichova J, et al (2003): Sanguinarine and chelerythrine: assessment of safety on pigs in ninety days feeding experiments. Food Chem Toxicol 42, 85-91.

19. Kozlowski K, Lecewicz A, Jeroch H, et al (2008): Effect of a phytogenic feed additive from Macleaya cordata on performance and carcass parameters of broilers. Arch Geflugelkd, 72, 140-142.

20. Kuribara H, Kishi E, Hattori N, et al (2010): The Anxiolytic Effect of Two Oriental Herbal Drugs in Japan Attributed to Honokiol from Magnolia Bark. J Pharm Pharmacol, 52, 1425-1429.

21. Leeson S, Summers JD (2001): Nutrition of the chicken. $4^{\text {th }}$ ed. University Books, Guelph.

22. Lima TRF, Gallo SB, Rosa AF, et al (2020): Effect of Macleaya cordata and Magnolia officinalis plant extractson oxidative stress control in lambs fed a highconcentrate diet. Asian-Australas J Anim Sci, 33, 913-920.

23. Lin Q, Zhao J, Xie K, et al (2017): Magnolol additive as a replacer of antibiotic enhances the growth performance of Linwu ducks. Anim Nutr, 3, 132-138.

24. Liu LL, He JH, Xie HB, et al (2014): Resveratrol induces antioxidant andheatshock protein mRNA expression in response to heat stress in black-boned chickens. Poult Sci, 93, 54-62.

25. Lo YC, Teng CM, Chen CF, et al (1994): Magnolol and Honokiol isolated from Magnolia officinalis protect rat heart mitocondria against lipid peroxidation. Biochem Pharmacol, 47, 549-553.

26. Mahady GB, Beecher CWW (1994): Quercetin-Induced Benzophenanthridine Alkaloid Production in Suspension Cell Cultures of Sanguinaria Canadensis. Planta Med, 60, 553-557.

27. Niu X, Fan T, Li W, et al (2012): The anti-inflammatory effects of sanguinarine and its modulation of inflammatory mediators from peritoneal macrophages. Eur J Pharmacol 689, 262-269.

28. NRC (National Research Council) (1994): Nutrient Requirements of Poultry: Ninth Revised Edition. The National Academics Press, Washington, D.C., USA.

29. Pang YL, Han XF, Bamikole MA, et al (2013): Antidiarrhea and anti-oxidant properties of Magnolol. Trop $\mathrm{J}$ Pharm Res, 12, 85-91.
30. Park EJ, Zhao YZ, Na M, et al (2003): Protective effects of honokiol and magnolol a tertiary butyl hydroperoxide or $D$ - galactosamine induced toxicity in rat primary hepatocytes. Planta Med, 69, 33-37.

31. Oh S, Gadde D, Bravo D, et al (2018): Growth-Promoting and Antioxidant Effects of Magnolia Bark Extract in Chickens Uninfected or Co-Infected with Clostridium perfringens and Eimeria maxima as an Experimental Model of Necrotic Enteritis. Curr Dev Nutr, 2, 1-10.

32. Shen JL, Man KM, Huang PH, et al (2010): Honokiol and magnolol as multifunctional antioxidative molecules for dermatologic disorders. Molecules, 15, 6452-6465.

33. Schmeller T, Wink M (1998): Utilization of Alkaloids in Modern Medicine. Springer, Heidelberg, pp. 435-459.

34. Simsek F (1999): Serbest Oksijen Radikalleri, Antioksidanlar ve Lipit Peroksidasyonu. Türkiye Klinikleri J Pediatr, 8, 42-47.

35. Soysal MI (2012): Biyometrinin Prensipleri. Namık Kemal Üniversitesi Yayınları, Tekirdağ, Turkey.

36. SPSS (1997): Statistical software for Windows version 7.5 Microsoft Windows. SPSS, Chicago, IL.

37. Tan LH, Zhang D, Yu B (2014): Antioxidant activity of the different polar solvent extracts of Magnolia officinalis leaves and purification of main active compounds. Eur Food Res Technol, 240, 815-822.

38. Vieira SL, Oyarzabal OA, Freitas DM, et al (2008): Performance of broilers fed diets supplemented with sanguinarine-like alkaloids and organic acids. J Appl Poult Res, 17, 128-133.

39. Wallace RJ, Oleszek W, Franz C, et al (2010): Dietary plant bioactives for poultry health and productivity. $\mathrm{Br}$ Poult Sci, 51, 461-487.

40. Wei YF, Long F, Da-Wen X, et al (2007): Comparison of pharmacological effects between different extracts of the leaf and bark of Magnolia officinalis. Nat Prod Res Dev, 19, 772-775.

41. Wen C, Gu Y, Tao Z, et al (2019): Effects of ginger extract on laying performance, egg quality, and antioxidant status of laying hens. Animals, 9, 1-9.

42. Windisch W, Schedle K, Plitzner C, et al (2008): Use of phytogenic products as feed additives for swine and poultry. J Anim Sci, 86, 140-148.

43. Yesilbag D (2007): Fitobiyotikler. J Res Vet Med, 26, 3339.

44. Yesilbag D, Gezen SS, Biricik H, et al (2013): Effects of dietary rosemary and oregano volatile oil mixture on quail performance, egg traits and egg oxidative stability of eggs in laying quails. Br Poult Sci, 54, 231-237.

45. Yesilbag D, Cetin I, Balci F, et al (2020): Effects of dietary supplementation of two commercial plant Extracts on the growth performance and ileal inflammation score in broiler chickens. Acta Vet Eurasia, 46, 68-74.

46. Zhang C, Kang X, Zhang T, et al (2019): Positive effects of resveratrol on egg-laying ability, egg quality and antioxidant activity in hens. Poult Sci, 28, 1099-1105. 